\title{
Distribution Strategy of Subsidized Fertilizer in Smallholder Oil Palm Plantation at Air Batu Subdistrict, Asahan District, North Sumatra
}

\section{Yogi Evand, Diana Chalil* and Rahmanta Ginting}

Department Agribusiness, Universitas Sumatera Utara, Indonesia

\begin{abstract}
Palm oil is an important commodity for Indonesia. It is an export oriented commodity with the highest export income contribution. Initially, Indonesian palm oil plantations were developed by major companies and since 1986, smallholders have started to establish. In 2018 , the share of smallholders has reached $42 \%$ of the total Indonesian oil palm plantation areas. However, unlike major companies, most smallholders' lack capital. Unfortunately, oil palm smallholders are not in the priority list of subsidized fertilizer recipients. As a result, smallholders have an average productivity that is still lower than private and state company plantations, which are $585.3 \mathrm{ton} / \mathrm{ha} /$ year and $5828 \mathrm{ton} / \mathrm{ha} /$ year, respectively. This does not only influence smallholder income but also the Indonesian palm oil industry. Therefore, this study will analyze subsidized fertilizer distribution for oil palm smallholders in Air Batu Subdistrict, Asahan District, which are determined purposively as one of the oil palm smallholding centers in North Sumatera. Data were collected from 1 (one) staff of the Agriculture office in Asahan, 2 (two) extension agents, 4 (four) fertilizer shopkeepers, and 24 smallholders in Air Batu. The agriculture office staff and extension agents were selected by purposive sampling based on their knowledge and responsibility in the distribution of subsidized fertilizers while shopkeepers and smallholders were selected with snowball sampling technique. Aside from timeliness, the overall distribution of subsidized fertilizer in Air Batu, Asahan is relatively good. Internal factors are negative since weaknesses are more dominant than strengths, while external factors are positive, since opportunities are more dominant than threats. The Asahan Agriculture Staff have made some fundamental changes, namely improving the management system both internally and externally. Therefore, they can use their strengths to overcome their weaknesses and threats to utilize the available opportunities as well as possible.
\end{abstract}

Keywords: distribution strategy, oil palm, subidized fertilizer

Received 24 December 2019 | Revised 17 December 2019 | Accepted 16 January 2020

\section{Introduction}

Palm oil is an important commodity for Indonesia. It is an export oriented commodity with the highest export income contribution. Initially, Indonesian palm oil plantations were developed by major companiesand since 1986, smallholders have started to establish.In 2018, the share of smallholders has reached $42 \%$ of the total Indonesian oil palm plantation areas [1]. However,

\footnotetext{
*Corresponding author at: Faculty of Agriculture, Universitas Sumatera Utara, Jl. Prof. Sofyan No. 3 Kampus USU Medan, 20155, Indonesia

E-mail address: diana3@usu.ac.id
} 
unlike majorcompanies, most smallholders lack capital. Consequently, their fertilizer usage cannot follow the recommended doses and types. Unfortunately, oil palm smallholders are not in the priority list of subsidized fertilizer recipients. As a result, smallholders have an average productivity that is still lower than private and state company plantations, which are 585.3 ton/ha/year and 5828 ton/ha/year, respectively [2]. Having a significant share of land, this condition does not only influence smallholder income but also the Indonesian palm oil industry. In addition, the allocation of subsidized fertilizer is still not evenly distributed to all agricultural subsectors, especially the estate subsector. From previous studies, Rahman's research shows that the fertilizer distributionbh system in Indonesia does not guarantee availability at the farm level. This is caused by the many weaknesses and various misunderstandings in its implementation [3]. Therefore,this study will analyze subsidized fertilizer distribution for oil palm smallholders and hopefully provide information to address the problems.

\section{Materials and Methods}

The study was conducted in Air Batu Subdistrict, AsahanDistrict, which are purposively determinedas one of the oil palm smallholding centers in North Sumatera. Data were collected from 1 (one)staff of the Agriculture office in Asahan, 2 (two) extension agents, 4 (four) fertilizer shopkeepers, and 24 smallholders in Air Batu. The agriculture office staff and extension agentsare selected through purposive sampling based on their knowledge and responsibility insubsidized fertilizer distribution while shopkeepers and smallholders were selected with snowball sampling technique. Subsidized Fertilizer Distribution Strategy in Smallholder Oil Palm Plantation in Air Batu is analyzed using SWOT technique by including 11 (eleven) strategic factors namely Realization of Definitive Plans for Group Needs, Realization Time, Budgeting Time, Regulations and Sanctions, Percentage of Average Selling Price, Fertilizer Redemption, Percentage of Cost Effect, Filling Time, Fertilizer Recommendation, Road and Distance Conditions and Fertilizer Store Location. These factors were classified into (a) Internal Factors, which can be controlled by the Department Agriculture office staff in Asahan and (b) External Factors, which cannot be controlled. The data were then scored and weighted. Scores are information on existing conditions were obtained from respondents and observations, which are based on indicators and parameters. For internal factors, score 1 and 2 are categorized as weaknesses, while 3 and 4 are categorized as strengths. For external factors, score 1 and 2 are categorized as threats while score 3 and 4 are categorized as opportunity. Weight is an important value of strategic factors that is calculated with pair comparisons technique with value 1,2 , or 3 , showing less, equal or more important for the factor in question compared to other factors [4]. The performance of subsidized fertilizer distribution is assessed by the accuracy in price, place, time, and amount as follows. 
Table 1. Accuracy Indicator Distribution of Subsidized Fertilizer

\begin{tabular}{|c|c|c|c|c|c|c|}
\hline \multirow{2}{*}{ No } & \multirow{2}{*}{ Aspect } & \multirow{2}{*}{ Indicators } & \multicolumn{4}{|c|}{ Score } \\
\hline & & & 1 & 2 & 3 & 4 \\
\hline 1 & Price & $\begin{array}{l}\text { Selling price difference in } \\
\text { percentage from the } \\
\text { determined price }\end{array}$ & $>6 \%$ & $>4-6 \%$ & $>2-4 \%$ & $0-2 \%$ \\
\hline 2 & Amount & $\begin{array}{l}\text { Received amount } \\
\text { difference in percentage } \\
\text { from the amount proposed } \\
\text { in RDKK }\end{array}$ & $0-25 \%$ & $>25-50 \%$ & $>50-75 \%$ & $>75 \%$ \\
\hline 3 & Place & $\begin{array}{l}\text { Number of distributors in } \\
\text { the subdistrict }\end{array}$ & 1 & 2 & 3 & 4 \\
\hline 4 & Time & $\begin{array}{l}\text { Receiving time difference } \\
\text { in month from the } \\
\text { proposed time in RDKK }\end{array}$ & $>6$ & $>5-6$ & $>4-5$ & $>3-4$ \\
\hline
\end{tabular}

\section{Results and Discussion}

\subsection{Implementation of Subsidized Fertilizer Distribution}

Figure 1 shows that subsidized fertilizer has a long distribution chain and submission mechanism. Based on the results, the performance factor of the accuracy can be seen in table 2 .

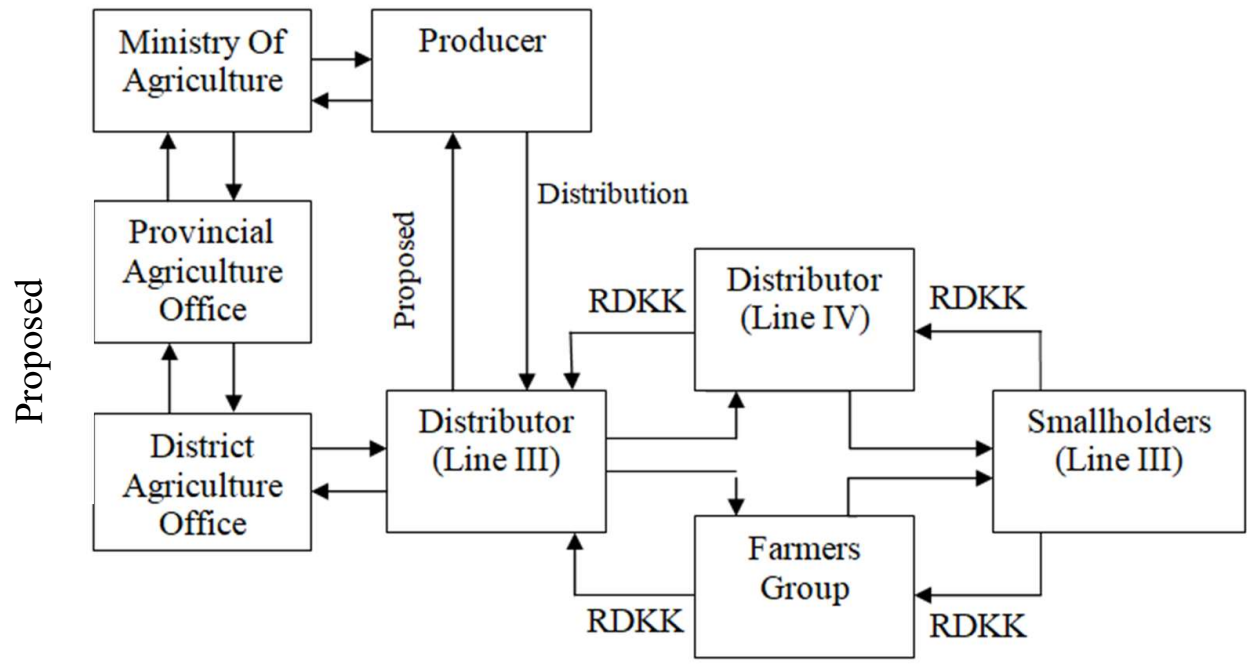

Figure 1. Subsidized Fertilizer Distribution

Based on respondent answers, price accuracy is dominated by respondents who answered between $0 \%$ to $4 \%$. This is due to the rule on HET limit, while other respondents receive differing prices due to transportation costs. Amount accuracy is dominated by respondents who reached more than $75 \%$. This is because subsidized fertilizer distribution is not in accordance with smallholder proposal. Place accuracy is dominated by respondents who answered that all shop owners are fertilizer sellers registered with the Agriculture Office, and all smallholders purchase subsidized fertilizer in that shop. Time accuracy shows that all respondents said there 
was a delay. This is due to the delay in submission by farmers, which affects distribution time. The average time needed is 5.5 months. From the four aspects of accuracy, it is found that the average score for each aspect of accuracy is as follows.

Table 2.Respondent Score in Subsidized Fertilizer Distribution

\begin{tabular}{lccccccccc}
\hline \multirow{2}{*}{ Aspect } & \multicolumn{8}{c}{ Parameter } & \multirow{2}{*}{ Total } \\
\cline { 2 - 8 } & $\mathbf{1}$ & $\mathbf{\%}$ & $\mathbf{2}$ & $\mathbf{\%}$ & $\mathbf{3}$ & $\mathbf{\%}$ & $\mathbf{4}$ & $\mathbf{\%}$ & \\
\hline Price & 3 & 12.5 & 6 & 25 & 7 & 29.2 & 8 & 33.3 & 24 \\
Amount & 1 & 25 & 0 & 0 & 0 & 0 & 3 & 75 & 4 \\
Place & 0 & 0 & 0 & 0 & 0 & 0 & 4 & 100 & 4 \\
Time & 0 & 0 & 2 & 50 & 2 & 50 & 0 & 0 & 4 \\
\hline
\end{tabular}

Table 3 shows that subsidized fertilizer distribution has a score of 3.25. This means that there are problems that still need to be fixed, namely price and timeliness. Price accuracy shows that there are still those who sell fertilizer not in accordance with the HET. Previous studies show that there are still problems in subsidized fertilizer distribution. Similar problems are also found in this study, namely time accuracy. Therefore, attention is needed to ensure fertilizer sales no longer exceed HET. Extended delays in subsidized fertilizer distribution are also still happening, affecting fertilization time.

Table 3. Performance Scores ofSubsidized Fertilizer Distribution

\begin{tabular}{ccc}
\hline No & Accuracy Indicator & Score \\
\hline 1 & Quantity & 4 \\
2 & Price & 3 \\
3 & Place & 4 \\
4 & Time & 2 \\
\hline & Average & 3.25 \\
\hline
\end{tabular}

\subsection{Scoring and Weighting of Internal and External Factors}

Based on the score and weight calculation of each strategic factor, details of the Internal Factors Analysis Strategic (IFAS) and External Factors Analysis Strategic(EFAS) table can be arranged as follows.

Tabel 4. IFAS Table

\begin{tabular}{|c|c|c|c|c|}
\hline & Internal Strategic Factors & Weight Value & Score & Weight $x$ Score \\
\hline \multicolumn{5}{|c|}{ Strenoth } \\
\hline 1. & Regulations and Sanctions & 0.19 & 3.7 & 0.70 \\
\hline \multirow[t]{2}{*}{2.} & Percentage of average selling price & 0.15 & 3.4 & 0.51 \\
\hline & Total Strength Value & & & 1.21 \\
\hline \multicolumn{5}{|c|}{ Weakness } \\
\hline 1. & Realization of RDKK & 0.25 & 2.3 & 0.58 \\
\hline 2. & Budgeting time & 0.18 & 2.3 & 0.41 \\
\hline \multirow[t]{3}{*}{3.} & Realization time & 0.23 & 1.3 & 0.30 \\
\hline & Total Weakness Value & & & 1.29 \\
\hline & Total & 1.00 & 16.8 & \\
\hline
\end{tabular}


Table 4 shows that regulations and sanctions is the most important and best strategic factor with a weight and score of 0.19 and 3.7, respectively. This reflects the strict regulations and sanctions applied by the Agriculture Office Staff, by revoking the permit for shop owners that sell fertilizer above HET, or sell subsidized fertilizer to smallholders who are not members of the group.However, the weight of weakness is higher than strength.

Table 5. EFAS Table

\begin{tabular}{rlccc}
\hline \multicolumn{2}{c}{ External Strategic Factors } & Weight & Score & Weight x Score \\
\hline Opportunity & & & \\
1. & Fertilizer store location & 0.17 & 2.6 & 0.36 \\
2. & Percentage of Cost Effect & 0.15 & 3.9 & 0.59 \\
3 & Road and Distance Conditions & 0.22 & 3.3 & 0.40 \\
\hline \multicolumn{2}{l}{ Total Opportunity Value } & & 1.35 \\
\hline Threat & & & \\
1. & Fertilizer recommendations & 0.16 & 1.9 & 0.30 \\
2. & Filing time & 0.19 & 1.8 & 0.34 \\
3. & Fertilizer Redemption & 0.24 & 2.3 & 0.55 \\
\hline & Total Threat Value & & 1.19 \\
\hline & Total & 1.00 & 13.5 \\
\hline
\end{tabular}

Table 5 Shows that filling time appears as the most flawed external factor with a weight value of 0.30 . In contrast, the percentage of cost effect has the highest score yet appears to be the least important for farmers do not take into account transportation costs too much. Therefore, these costs are considered as fixed costs that must be incurred. Overall, the total opportunity weighted score is still higher than threats.

Given the total difference of internal and external factor weighted scores, the position of the subsidized fertilizer distribution strategy in Air Batu is presented in the Cartesian diagram in Figure 2. 


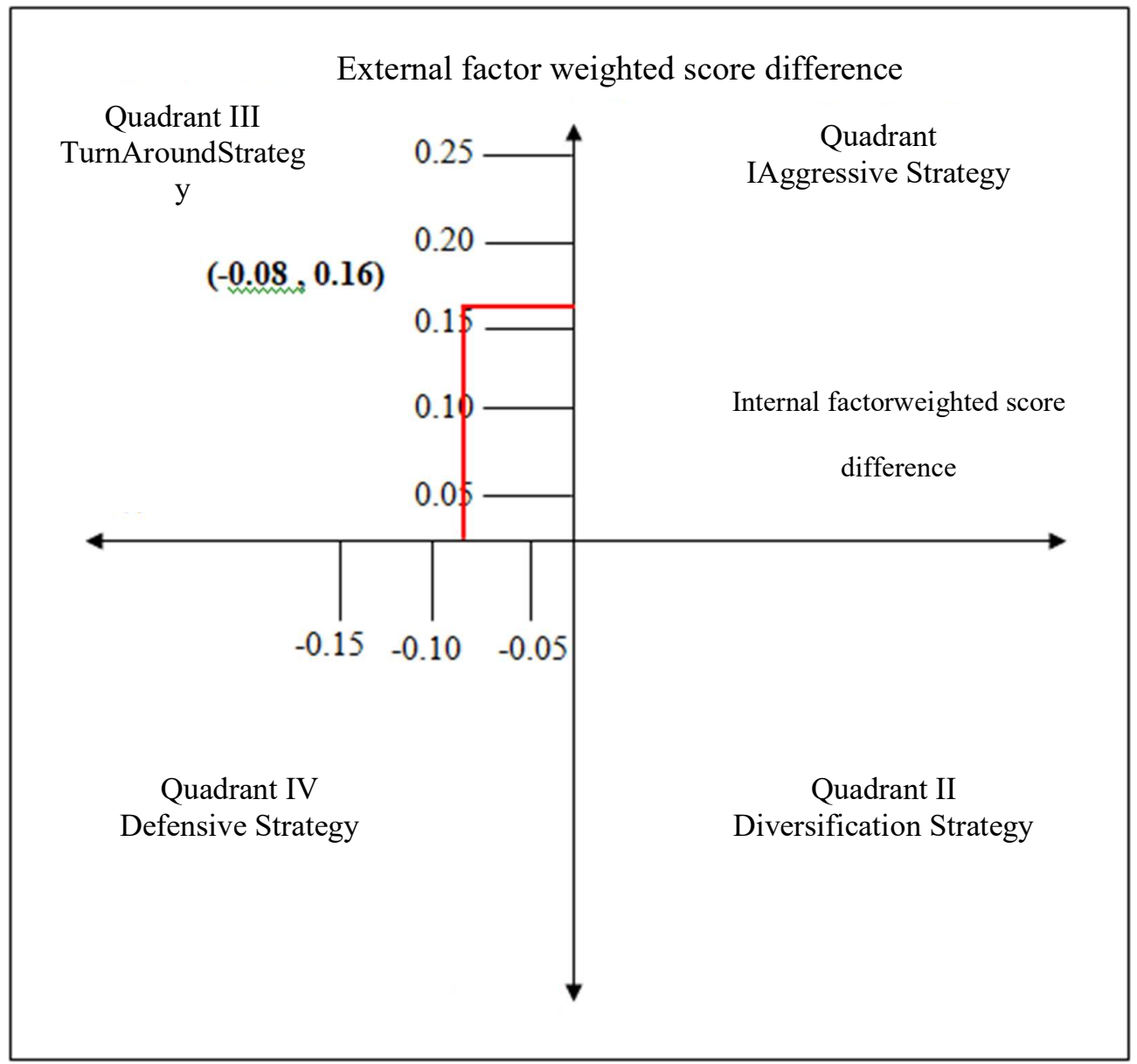

Figure 2. SWOT Position Matrix

Figure 2 shows the position of the fertilizer distribution strategy in Air Batu in Quadrant III refers to theturnaround strategy. This means that subsidized fertilizer distribution has good opportunity but turn around strategy suggests staff to under go fundamental changes such as changing the submission and budgeting system to overcome all problems related to time, from filing to realization or distribution time. This is the fundamentalproblem in subsidized fertilizer distribution in Air Batu. If the problems can be overcome, opportunities can be utilized thoroughly. Alternative strategies for distributing subsidized fertilizers in Air Batuis presented in Table 6. 
Table 6. Alternative Strategies for Subsidized Fertilizer Distribution in Air Batu District

\begin{tabular}{|c|c|c|}
\hline IFAS & $\begin{array}{l}\text { Strength } \\
\text { 1. Regulations and } \\
\text { Sanctions } \\
\text { 2. Percentage of average } \\
\text { selling price }\end{array}$ & $\begin{array}{l}\text { Weakness } \\
\text { 1. Realization of RDKK } \\
\text { 2. Budgeting time } \\
\text { 3. Fertilizer Redemption } \\
\text { 4. Time of Realization }\end{array}$ \\
\hline Opportunity & SO Strategy & WO Strategy \\
\hline $\begin{array}{ll}\text { 1. Fertilizer store } \\
\text { location } \\
\text { 2. Road and Distance } \\
\text { Conditions } \\
\text { 3. Percentage of Cost } \\
\text { Effect }\end{array}$ & $\begin{array}{l}\text { 1. Not changing existing } \\
\text { regulations and sanctions, } \\
\text { so that with current road } \\
\text { conditions and distance, as } \\
\text { well as the location of the } \\
\text { fertilizer shop that reaches } \\
\text { all group members, the } \\
\text { continuity of subsidized } \\
\text { fertilizer distribution is } \\
\text { guaranteed (S1-O1,O2) } \\
\text { 2. Use regulations and } \\
\text { sanctions to ensure selling } \\
\text { prices are in accordance } \\
\text { with the HET, so that the } \\
\text { cost of distributing } \\
\text { fertilizer issued by } \\
\text { smallholders remains stable } \\
\text { (S1, S2-O3). }\end{array}$ & $\begin{array}{l}\text { 1. Reviewing the reasons for } \\
\text { the low redemption of } \\
\text { subsidized fertilizer so that } \\
\text { it can maximize the } \\
\text { fertilizer that will be } \\
\text { distributed to shops, so that } \\
\text { the availability of fertilizer } \\
\text { in shops is optimal (W1, } \\
\text { W3-O1). } \\
\text { 2. Improve the budgeting and } \\
\text { distribution system so that } \\
\text { good road conditions and } \\
\text { distances can accelerate the } \\
\text { distribution of subsidized } \\
\text { fertilizer (W2, W4-O2). }\end{array}$ \\
\hline Threats & ST Strategy & WT Strategy \\
\hline $\begin{array}{l}\text { 1. Fertilizer } \\
\text { recommendations } \\
\text { 2. Filing time }\end{array}$ & $\begin{array}{l}\text { 1. Maximizing the role of } \\
\text { extension workers in } \\
\text { determining fertilizer } \\
\text { requirements so that the } \\
\text { proposed fertilizer can be } \\
\text { effective to meet the needs } \\
\text { of all smallholders (S1-T1) } \\
\text { 2. Implement the RDKK } \\
\text { Online system so that it can } \\
\text { cut the filing time. (S1-T2) }\end{array}$ & $\begin{array}{l}\text { 1. Maximizing the role of } \\
\text { extension workers in } \\
\text { socializing the importance } \\
\text { of the suitable fertilization } \\
\text { amount, so that fertilizer } \\
\text { that is realized to farmers } \\
\text { can be redeemed in } \\
\text { accordance with the } \\
\text { proposed RDKK (W1,W3- } \\
\text { T1) } \\
\text { 2. Improve the management } \\
\text { system in the farmer group } \\
\text { so that the filing time can } \\
\text { be more optimal, } \\
\text { ultimately improving } \\
\text { budgeting and realization } \\
\text { time (W2, W4-T2) }\end{array}$ \\
\hline
\end{tabular}

\section{Conclusion and Recommendation}

\subsection{Conclusion}

Aside from timeliness, the overall distribution of subsidized fertilizer in Air Batu Subdistrict, Asahan Districtis relatively good. This is mainly stemmed from the realization time and fertilizer recommendation. Both are not the most important factors, Although the current condition is inadequate. To address this, the Asahan Agriculture Staff need to make some changes such as modifying the submission and budgeting system to overcome all problems related to time, from filing to realization and distribution time. This is the fundamental problem 
in subsidized fertilizer distribution in Air Batu. If the problem can be overcome, opportunities can be utilized thoroughly.

\subsection{Recommendation}

The government, in this case the Asahan Regency Agriculture Service, must be faster in management by implementing an online system to speed up distribution time. In addition, the role of agricultural extension workers must be further maximized in helping farmer groups to prepare the fertilizer budget, so that distributed fertilizer can be in accordance with the proposed RDKK. Furthermore, smallholder oil palm farmers must also adjust their fertilizer needs according to the existing recommendations, so that distributed fertilizer is in accordance with what the smallholder oil palm farmers require. It is hoped that researchers will be able to see a variety of other strategic factors which have not been included in this study in accordance with the current conditions. In addition, in the calculation of the number of respondents and research locations, the scope can be expanded.

\section{REFERENCES}

[1] Badan Pusat Statistik Provinsi Sumatera Utara. 2017.

[2] Buku Saku Kabupaten Asahan dalam Angka. 2018.

[3] B. Rachman, Kebijakan Subsidi Pupuk: Tinjauan Terhadap Aspek Teknis, Manajemen, dan Regulasi. 2016.

[4] T. L. Saaty, Pengambilan Keputusan Bagi Para Pemimpin, PT. Bustaman Binaman Presindo, Jakarta, 1998. 